\title{
The Reform of EFL Teachers' Professional Development in Secondary Vocational Schools: an Ecological Perspective
}

\author{
Shiyong Jiang \\ School of Foreign Languages, Leshan Normal University, Leshan, Sichuan, China
}

jsy2002@126.com

\begin{abstract}
Keywords: Secondary vocational school EFL teachers; Professional development; Professional spirit; Ecological perspective; Reform
\end{abstract}

\begin{abstract}
For a long time, EFL teaching in secondary vocational schools has been in a periphery position, causing the lower quality of teaching. Nowadays, with the rapid development of vocational education in China, it is a key requirement to reconstruct EFL teachers' professional spirit with the emphasis on their professional identities. Starting from an ecological perspective, this paper analyzes the reconstruction of EFL teachers' professional spirit, social and professional status in vocational context, and provides some suggestions for their professional development.
\end{abstract}

\section{Introduction}

In the framework of vocational education in China, the task of secondary vocational schools (briefly for vocational schools) is mainly to cultivate talents with intermediated-level professional skills for the factories, and therefore, skill teaching is the most important for both students and the school. English teaching has always been a hard nut to crack, and English teaching has always been neglected in the research of EFL teacher development for years. Although officially, there are a number of programs for teacher's professional development, the effectiveness is restricted by the way there are arranged, of which, the orientation is that teacher development is mainly skill training.[1] However, from an overall perspective, EFL teachers in vocational school exist in their own ecological environment, connected with the school, colleagues, students and other social factors. With such an illumination, EFL teachers' professional development should be studied in an ecological framework to ensure the balance among these factors and the long-term effectiveness of development. One problem of vocational school EFL teachers' development is that the present program separates the training from the whole of teachers' professional ecology, far away from long-term effectiveness. As "social beings", teachers' agency, awareness and spirit of professional development have been ignored greatly. Specifically, vocational English teachers' development has been limited to the "technique level" with the lower ecological status of teachers in the school. Currently, there are not many researchers noticing the effective development model of vocational EFL teachers from an ecological perspective. Therefore, this paper, based on the study of ecology, probes into the current model EFL teachers' development in vocational schools, and provides some suggestions for the change of teachers' professional development from being "instrumental" to being "ecological".

\section{Current Situation of ELT Teachers' Professional Development in Vocational Schools}

Vocational English is one of the essential components of humanity education in vocational schools. Nevertheless, due the lower ecological status of English teachers in vocational school and the tradition of teacher development, the motivation of teacher development mainly originated from the official requirement bottom up. For example, there could be the requirement that a teacher must be trained for a certain period of time, such as 40 hours per term. However, relying more on the external forces would be harmful for teachers' agency and initiatives in the development. According to one study in Sichuan province, only 32.2\% vocational English teachers in the questionnaire will 
think of development, and 53.3\% teachers think that the effectiveness was not as expected. Besides, the majority of teachers did not have sufficient opportunities to go out for further development.[2] An interview with some teachers from Sichuan and Chongqing also showed that even though teachers have the will to learn, they are lack of chances. Meanwhile, the mode of their development is mainly teaching training in the traditional way which in effect is not very useful. In fact, treating teachers as "the technique being" is the direct pursuit for "skills" which ignores the nature of teachers as "social beings". Much worse, many vocational schools do not view English teachers as equal as skill teachers, investigating less and focusing less on their development. All these factors caused the lower motivation or initiatives in their professional development. Of course, such a low ecological status and sole training model cannot adapt to the trend of vocational education in China. In recent years, the strategy of vocational education has been emphasized by the government with many policies made for its promotion. In such a new and promising period, it is a must to carry out timely reforms of vocational English teaching and teacher development from an ecological perspective which takes both the internal and external factors into serious consideration.

\section{Vocational EFL Teachers' Professional Development from an Ecological Perspective}

Ecology is a discipline which has been noticed and utilized in many aspects of social science. According to the studies in ecology, everything in the nature is in certain ecological environment and forms an interconnected complex system with other factors. One important issue is to maintain the balance between elements of the system. Once the balance is lost, the system will be destroyed or changed drastically. [3] In the ecological system of vocational school, English teacher is also a dynamic ecological individual and maintain their status in a balanced environment. As what Professor $\mathrm{Gu}$ [4] has mentioned, it is necessary to change the conditions of teacher development, such as the knowledge, abilities, attitudes, etc, so as to improve the adaptability of education for technological and social reforms. Surely, teacher development is not limited merely in skills, but also in their professional attitude, motivation, pursuit, and is influenced by the environment related to these factors. The reform indicates that the single model of skill training must be changed. As a social being, the teacher's ecological features must be cared seriously. It is essential that EFL teachers' knowledge of English, knowledge of teaching in vocational school, internal motivation, attitude toward vocational English teaching and developmental conditions must be integrated to form a balanced ecological system. Therefore, on the one hand, there must be the development of teachers' professional cognition, pursuit, so as to reconstruct their professional spirit; on the other hand, there must be consideration of the reality of teachers' career. Then, based on such a mechanism, suitable ways can be chosen for training and learning. The two aspects are interrelated closely and exist in the whole process of teachers' development.

A healthy and balanced mode of teacher development requires the integration of all the factors like professional spirit, professional behavior and the required environment to generate strong motivation for development in reality. From the ecological point of view, the professional spirit is in the center which controls or influences other factors. To realize the effectiveness of development, it's essential to construct a harmonious professional ecology, change teachers' idea of teaching English in vocational school, rebuilt their spirit of teaching to form the positive spirit of professional pursuit and make it one part of teacher' professional life.[5] For administrators, the ideology of management must also be altered accordingly, that is, the school needs to combine the internal development of teachers and the affordance of platform or conditions together. In an ecological field which concentrates on balance among connections, all teachers should be regarded as the indispensable part of education. EFL teachers must be respected, treated equally with skill teachers, and they also have the right to develop and contribute to the cultivation of students. It is essential that EFL teachers experience respect, achievements and value of their professional life in their career of teaching, which in turn will promote their teaching, forming a related balanced ecological system. 


\section{The Reform of EFL Teachers' Professional Development in Vocational Schools}

All is considered, it is high time that there were reforms in vocational school EFL teachers' development. Based on an ecological perspective, a unified and practical model of teachers' development can be figured out with their professional spirit, design of the development in a unified way and the environment of development be incorporated.

Reconstruct Teachers' Professional Spirit in Secondary Vocational Environment. Spirit is always related to teachers' responsibility and agency in their work. As one of the most important factors in vocational English teachers' professional ecology, spirit covers teachers' awareness of the profession, their cognition, attitudes and the values toward the job which directly affect their behavior and the amount of time and energy spent on the developmental activities. [6] Only when teachers have the positive spirit of loving and contributing to the profession can they develop themselves with their own initiatives and agency in the long run. Although teachers may have strongly held beliefs, they do not always put these into practice. The reasons need to be understood by exploring the specific contexts in which they work, each of which is itself a complex and dynamic system.[7] Due to the "vocation" orientation and students' lower proficiency of English in vocational schools, the teacher must form rational cognition of English teaching in vocational education field, understand the reality of vocational students so that he or she can have a satisfied self-cognition and develop himself or herself accordingly. Currently, with the trend of emphasizing vocational education both in vocational schools and colleges, it is effective to form the cultural ecology of teachers in schools and establish the development platform in order to prompt teachers to change their ideas of developing. For teachers, they need to identify themselves as the contributors to students' learning and adapt themselves to English teaching in secondary vocational education. For schools, it has the responsibility to build a positive and harmonious culture which will in turn promote teachers to reconstruct their spirit and pursuit of teaching English effectively in a secondary vocational environment. In doing so, it is necessary that the school should care English teachers, respect them, and treat English teacher equally with other teachers. It will be of help for English teachers to experience the "power" and "responsibility" in teaching and realize a balance in the ecological environment of vocational English teaching.

Make a Feasible Ecological-oriented Top-level Design of Teacher Development. Vocational school teachers are in a unique ecological system and therefore all the possible ecological factors must be taken into good consideration in the design of professional development. Starting from an ecological perspective, there must be a top-level design which emphasizes the optimistic management and governs the detailed professional activities in vocational schools. As the innovation, this design must stress on the humanistic nature of English teachers, focuses on how to develop English teachers effectively through reconstructing their professional spirit, stimulating them and protecting their rights of being an excellent language teacher in vocational education. In the whole framework, there should be not only the incorporation between "spirit" and "techniques" of teachers, but also the post-training measures that ensure the application of teachers' newly acquired experience, knowledge or skills in a normal manner. Within a top-level design, the features of English teachers must be examined carefully, and mechanisms governing teacher training at all levels should be established with the avoidance of prejudice over teachers of humanities. For example, the diagnostic mechanism which examines what contents and ways of training are required, the executive mechanism that determines how the training can be carried out effectively and the evaluation and stimulation mechanism which ensure the actual efficacy of training must be formed with the cooperation between the executives and teachers of the school. In a word, ecologically, there should be changes from being "prescribed" to being "self-initiated" or "self-controlled" so that a balanced and circulated developmental mechanism can be built which determines how the school will develop and how students can be cultivated in the long run.

Realize the Ecological Balance of Teachers' Professional Development in Vocational Schools. As what have been discussed, vocational school English teachers are not just "professionals", but also complete "social beings". Their affection, psychology, pursuit and values must all be respected 
and become the precondition of their professionalisation. It is only when the contradiction between teachers' life and profession is minimized can professional development become imprinted in teachers in the long run. The innovation requires the integration of teachers' development both internally and externally. For school administration, it is beneficial to apprehend English teachers' professional autonomy, their professional pursuit and motivation which had been neglected for a long time in vocational schools. Specifically, the school leaders must change the idea of stuff training, especially paying attention to English teachers' ecological nature so as to avoid ignoring "humanity teaching" in vocational schools. To consider the internal and external factors of teacher development, the school should empower English teachers to determine how to develop and provide necessary financial and professional support. Like skill teachers, English teachers have the same right to be trained or to go outside for further development. As noted in Vygovsky's Socio-cultural Theory, negotiation or dialogic mediation between teachers and the school authority should be appealed.[8] Therefore, more power and freedom must be given to English teachers to make them be self-responsible for professional behavior. As a result, through the cultivation of spirit pursuit and practical skill training, the balance of English teachers' profession can be realized gradually.

Reform the Specific Modes of Teacher Development. First of all, schools should make full use of and innovate the existing modes of English teacher development. As is known to all, traditional modes of English teacher development are mostly skill-oriented and are lack of the support of spiritual "soil". From an ecological viewpoint, the development mode, like school-based development, has to be reconstructed and lead to the improvement of teachers' overall abilities to deal with the practical situation. With schools as the place for development and teaching as the act of belonging [9], the time, content and manner can all be negotiated according to teachers' actual professional condition. Therefore, ecologically, ELT teachers' development must be reformed from being external to being internal and from being closed to being open, so as to take teaching of vocational students' English as the pursuit of the value of the life.

Second, there must be creative and novice mechanism of teaching training based on the support from awareness-raising and motivation stimulation of English teachers. The traditional way of expert-dominated mode is still helpful in some ways, that is, it is convenient for more teacher to get together to listen to the lecture and learn skills or experience. However, this type of training is separated from classroom and when the trained teachers come back, they might still be dominated by the primary factors, causing no changes at all.[10] Therefore, novice modes of training must be developed at all levels, changing the beliefs of both the trainer and trainees ecologically, making the interaction more prominent so that EFL teachers' professional development can be led really effectively by the specialists.

Third, EFL teachers must pay attention to the integration of teaching and research together. As researches indicated, many vocational English teachers focused on teaching merely while ignored the work of study of their teaching. They had little awareness of reflecting on and studying their own teaching and students' learning, especially English learning for students with lower proficiency and learning motivation in vocational environment. Seldom did vocational English teacher engage in research projects as observed by some scholars in China.[2] This reality makes learning only exist at a lower level, and teachers can only see "the trees" of English teaching rather than "the forest" of English education. However, researches and teaching are always mutually supportive and can benefit one another. Based on the ecological point of view of vocational education, the development of vocational English teacher must not ignore the atmosphere of research, guide teachers to form the concept of "teaching and research are mutually beneficial", realize the great value of researching teaching in order to promote teaching through research. Vocational schools need to build platforms for school-based research and provide necessary financial and spiritual support to ensure the mutual promotion of teaching and research. This is not only beneficial for improving teaching quality, but also for strengthening EFL teachers' professional confidence and their internal developmental motives. 


\section{Conclusions}

For years, the phenomenon of "strengthening more on skills and less on humanities" in vocational schools hampered English teaching effectiveness in a rooted way. To help English teaching walk out from the periphery position, there is the need for the cooperation between EFL teachers and other ecological factors, like the school, the society, and so on. From an ecological perspective of teachers' development, we need to treat teachers as social beings, focusing on teachers both spiritually and professionally. To ensure a better result of EFL teachers' development, it's necessary to increase EFL teachers' ecological status and overcome the demerit of segregation among professional awareness, professional spirit and practical skill training. To develop teachers ecologically, we must on the one hand promote teachers to reflect on their inner world of profession, such as their value, awareness, motivation and pursuit in the profession on the one hand, and based on the ecological perspective of development, improve the efficacy of professional training, learning and other practical activities so as to help teachers experience success in their profession and thus form the effective developmental modes in a normal condition. In a word, from an ecological point of view, to achieve the long-term effectiveness of EFL teachers' professional development in secondary vocational schools, there must be cooperation among all the parties involved, such as EFL teachers themselves, the educational administrations, vocational schools and so forth so that teachers' development is a unified whole rather than separated trainings or seminars which can only exert influences within a limited period of time.

\section{Acknowledgements}

This research is founded by the National Basic Foreign Language Research Project: Research on the Intensive Professional Development of EFL Teachers in Primary and Secondary Schools (Grant number: JJWYYB2015015 )

\section{References}

[1] Y. Zhang and Z. J. Xu. An Investigation into the Training Condition of Vocational School English Teachers, Journal of ShanXi Normal University, (2012) No. 3, p155.

[2] R. S. Lai. An Investigation into the Present Status of Vocational School English Teachers' Professional Development. English Teaching and Research Notes, (2012) No.11, p34-37.

[3] M. Q. Sutton, \& E. N. Anderson, Introduction to Cultural Ecology. Altamira Press, United States, 2004

[4] M. Y. Gu. A Dictionary of Education. Shanghai Education Press. China, 1997.

[5] S. G. Xu. Self-developing of Teachers: Cases from Successful Teachers, Foreign Language Teaching and Research Press, China, 2008.

[6] Y. Li. Exploring the Mechanism of Balancing Teachers' Professional Pressure and Motives. Modern Education in Primary and Secondary Schools, (2013) No. 6, p57-60.

[7] D. Larsen-Freeman and L. Cameron. Complex Systems and Applied Linguistics. Oxford University Press, Britain, 2008.

[8] E. K. Johnson. Second Language Teacher Education A Sociocultural Perspective, Routledge, United States, 2009.

[9] M. Clarke. Language Teacher Identities: Co-constructing Discourse and Community, Multilingual Matters, United States, 2008.

[10]L. Xu. On the Cultural Mechanism of Teacher Development. Journal of Northwest Normal University, (2007) No. 5, p68-71. 